\title{
EDITORIAL
}

\section{MEUS NOVOS E QUERIDOS COLEGAS DE 2002/1}

Na noite de ontem tivemos uma das solenidades acadêmicas que mais me agradam: nossa formatura informal, logo após o Culto Ecumênico, onde aconteceram agradecimentos de pais, e de vocês mesmos, à Universidade pública, Gratuita e de Qualidade.

Pública, sim; mas a gratuidade resulta da contribuição que todos os cidadãos fazem neste País, através de tributos aos governos municipal, estadual e federal. No atual Governo Federal, notou-se a ausência financeira para a manutenção das Universidades Federais. Atitudes de protesto foram tomadas pelos docentes e pelos técnicos-administrativos das Instituições Federais de Ensino Superior. A resultante destes movimentos é que estamos formando em novembro a turma que corresponde ao semestre 2002/1.

Nossas atitudes de protesto não foram consideradas, e conseqüentemente aguardamos com ansiedade e expectativa as medidas relativas ao ensino superior do novo governo federal, a partir de janeiro de 2003, para que possamos, com mais tranquiilidade, continuar oferecendo à comunidade, profissionais técnica e cientificamente capacitados e que não nos custem tanto sacritício pessoal como hoje.

Neste sentido, pedimos àquelas pessoas que se manifestaram na cerimônia da noite de ontem, na qual agradeceram uma universidade pública, gratuita e de qualidade como instrumento para obtenção de seus objetivos e ideais, que sejam nossos porta-vozes junto à Comunidade.

Vocês, meus queridos colegas, se constituem numa Turma de exceção. Porque digo isso? Porque demonstraram ter uma sensibilidade muito grande, primeiramente pela escolha do paraninfo, prof. Pantelis Varvaki Rados, que é meu filho intelectual, bem como pela escolha dos demais homenageados. Em segundo lugar, porque estando Diretor há cinco anos, tive a oportunidade de presidir 10 solenidades de formatura, e esta é a primeira vez que vejo uma turma prestar uma homenagem tão preciosa, tão carinhosa, aos pais, como a de hoje, e como a de ontem.

Sejam felizes, podeis exercer a odontologia. Muito obrigado

Prof. J. J. Barbachan Diretor 